\title{
Subcutaneous to visceral fat ratio: a possible risk factor for metabolic syndrome and cardiovascular diseases
}

This article was published in the following Dove Press journal:

Diabetes, Metabolic Syndrome and Obesity:Targets and Therapy

\author{
Muhammad Nabeel Shafqat' \\ Miqdad Haider ${ }^{2}$ \\ 'Department of Medicine, University \\ of Medical Sciences "Serafin Ruiz de \\ Zarate" Villa Clara (UCMVC), Villa \\ Clara, Cuba; ${ }^{2}$ Department of Internal \\ Medicine, Fatima Memorial Hospital, \\ Fatima Memorial College of Medicine \\ and Dentistry, Lahore, Pakistan
}

\section{Dear editor}

We would like to comment, with great interest, about the recently published article "Visceral-to-subcutaneous fat ratio as a predictor of the multiple metabolic risk factors for subjects with normal waist circumference in Korea" by Oh et al, ${ }^{1}$ which we found very interesting and valuable. This study is a good step to determine the predictive value of visceral-to-subcutaneous fat ratio (VSR) in persons with normal waist circumference for the diagnosis of risk factors for metabolic syndrome.

Metabolic syndrome is defined as a cluster of risk factors that occur together, resulting in a high risk of cardiovascular diseases, cerebrovascular events, and diabetes mellitus. At least three of the five main metabolic risk factors - abdominal obesity, high blood pressure, increased blood glucose level, increased serum triglycerides, and decreased high-density lipoprotein cholesterol - must be present in order to make a diagnosis of metabolic syndrome. According to the guidelines from National Heart, Lung and Blood Institute and American Heart Association, these risk factors are defined as following: abdominal obesity defined as a waist circumference $\geq 102 \mathrm{~cm}$ in men and $\geq 88 \mathrm{~cm}$ in women, blood pressure $\geq 130 / 85 \mathrm{mmHg}$, fasting blood sugar level $\geq 100 \mathrm{mg}$ / $\mathrm{dL}$, serum triglycerides $150 \mathrm{mg} / \mathrm{dL}$ or above, and high-density lipoprotein cholesterol $\leq 40 \mathrm{mg} / \mathrm{dL}$ and $\leq 50 \mathrm{mg} / \mathrm{dL}$ in men and women, respectively. ${ }^{2}$

Obesity is a heterogeneous condition, and regional distribution of fat is important to understand the role of obesity in disturbances of lipid and glucose metabolism. Adipose tissue, in obese patients, can accumulate in subcutaneous areas as well as visceral parts of abdomen. There are anatomical, physiological, clinical, and prognostic differences between subcutaneous and visceral fat. Visceral fat has been associated with greater risk of developing heart disease, cerebrovascular conditions, and diabetes compared to subcutaneous fat. ${ }^{3}$

In this cross-sectional study, the authors compared visceral fat area, subcutaneous fat area, and VSR in order to determine if VSR has any role in determining the metabolic risk factors in persons with normal waist circumference. The study results showed that VSR can predict the presence of nonadipose metabolic risk factors in men with normal waist circumference, but in the case of women, the results were nonsignificant with $p$-value $>0.05$.

We reviewed few other studies on association of VSR as a risk factor for metabolic syndrome and cardiovascular diseases which also show significant results. The study by Kaess et $\mathrm{al}^{4}$ showed a significant correlation between the ratio of visceral adi-
Correspondence: Miqdad Haider Department of Internal Medicine, Fatima Memorial Hospital, Fatima Memorial College of Medicine and Dentistry, Shadman, Lahore, 54000, Pakistan Email miqdadI4@yahoo.com 
pose tissue to subcutaneous adipose tissue and cardiovascular diseases. Another study conducted in Japan concluded that there is a dose-dependent response between visceral fat area and risk for metabolic syndrome in normal weight population. ${ }^{5}$

We recommend that further studies should be conducted in order to consider VSR as an established risk factor for metabolic syndrome and cardiovascular diseases. Moreover, VSR may give worthwhile information for interventions to improve risk factors for metabolic syndromes and cardiovascular diseases.

\section{Disclosure}

The authors report no conflicts of interest in this communication.

\section{References}

1. Oh YH, Moon JH, Kim HJ, Kong MH. Visceral-to-subcutaneous fat ratio as a predictor of the multiple metabolic risk factors for subjects with normal waist circumference in Korea. Diabetes Metab Syndr Obes. 2017;10:505-511.

2. Stoppler MC. Medicinenet. Available from: https://www.medicinenet. com/metabolic_syndrome/article.htm\#how_is_metabolic_syndrome_ defined. Accessed March 17, 2016.

3. Wajchenberg BL. Subcutaneous and visceral adipose tissue: their relation to the metabolic syndrome. Endocr Rev. 2000;21(6):697-738.

4. Kaess BM, Pedley A, Massaro JM, Murabito J, Hoffmann U, Fox CS. The ratio of visceral to subcutaneous fat, a metric of body fat distribution, is a unique correlate of cardiometabolic risk. Diabetologia. 2012;55(10): $2622-2630$.

5. Tatsumi Y, Nakao YM, Masuda I, et al. Risk for metabolic diseases in normal weight individuals with visceral fat accumulation: a crosssectional study in Japan. BMJ J. 2017;7(1):8.

Dove Medical Press encourages responsible, free and frank academic debate. The content of the Diabetes, Metabolic Syndrome and Obesity: Targets and Therapy 'letters to the editor' section does not necessarily represent the views of Dove Medical Press, its officers, agents, employees, related entities or the Diabetes, Metabolic Syndrome and Obesity: Targets and Therapy editors. While all reasonable steps have been taken to confirm the content of each letter, Dove Medical Press accepts no liability in respect of the content of any letter, nor is it responsible for the content and accuracy of any letter to the editor.

Diabetes, Metabolic Syndrome and Obesity: Targets and Therapy is an international, peer-reviewed open-access journal committed to the rapid publication of the latest laboratory and clinical findings in the fields of diabetes, metabolic syndrome and obesity research. Original research, review, case reports, hypothesis formation, expert opinion and commentaries are all considered for publication. The manuscript management system is completely online and includes a very quick and fair peer-review system, which is all easy to use. Visit http://www.dovepress.com/testimonials.php to read real quotes from published authors.

Submit your manuscript here: https://www.dovepress.com/diabetes-metabolic-syndrome-and-obesity-targets-and-therapy-journal 